\title{
FISHERIES MANAGEMENT AND OCEAN OBSERVATIONS
}

\author{
David M. Checkley, Jr.
}

\author{
Scripps Institution of Oceanography, La Jolla, California 92093-0218 USA \\ Email: dcheckley@ucsd.edu
}

\section{ABSTRACT}

Ocean observations are rarely used at present in fisheries management. Canonical management of fisheries assumes density dependence. Future management will consider the ecosystem and occur in a changing climate. Hence, ocean observations will be increasingly used. These will include measurements of the atmosphere, ocean, and socioeconomic variables. Indexes of population or ecosystem state are used, particularly in integrated ecosystem assessments. Acoustics, optics, and molecular sensors deployed on a wide variety of platforms will contribute to observing for assessment and forecasting in fisheries. While many challenges exist, including the need for increased focus on coastal regions, ocean observations are predicted to become essential to fisheries management by OceanObs'19.

\section{INTRODUCTION}

Ocean observing is critical to the management of only a few fisheries at present. The future needs of fisheries management and capabilities of ocean observing will undoubtedly lead to greater reliance of management on observations. Acknowledgement and participation of this by both the management and observing communities are needed. In this paper, the needs and opportunities of ocean observing for fisheries management are briefly presented.

A marine fishery is the removal of fish, including invertebrates, from the sea by humans. Three characteristics of marine fisheries are noted. First, fisheries target stocks of single species of fish, affecting not only those stocks but also their environment [1]. Second, fishers, not fish, are managed [2]. Third, climate and fishing together affect fished populations [3 and 4]. Thus, the management of fisheries is made difficult because the fished populations are affected by a changing environment and humans with their associated behavior.
Marine capture fisheries reached a global maximum of $\sim 70$ million metric tons per annum in the late 1980s (Fig. 1) [5]. Global aquaculture has increased rapidly and continues to do so [5], as the demand for seafood continues to increase with world population growth. Aquaculture relies on capture fisheries for food, enhancing demand for the latter.

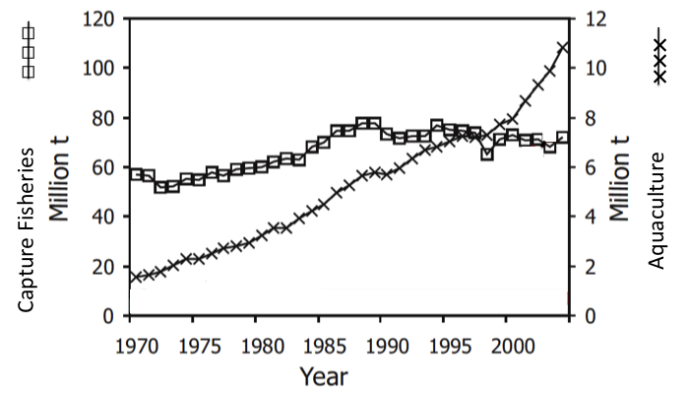

Figure 1. Annual marine production of capture fisheries and aquaculture, excluding China. [5]

Most fish are captured in coastal regions (Table 1) [6] where observing, understanding, and models are often less well developed than for oceanic regions. Ironically, the environments of productive regions (e.g., upwellings and high latitudes) are often less easily observed due to ocean and atmosphere conditions (e.g., aerosols, clouds, fog, wind, and seas). Many regions have smaller, often artisanal, fisheries [7]. Data on fish for fisheries management are either

FAO

$\begin{array}{ll}\text { Peruvian anchoveta } & 7007157 \\ \text { Alaska pollock } & 2860487 \\ \text { Skipjack tuna } & 2480812 \\ \text { Atlantic herring } & 2244595 \\ \text { Blue whiting } & 2032207 \\ \text { Chub mackerel } & 2030795 \\ \text { Chilean jack mackerel } & 1,828999 \\ \text { Japanese anchovy } & 1,656906 \\ \text { Largehead hairtail } & 1587786 \\ \text { Yellowfin tuna } & 1129415\end{array}$

Table 1. Ten top marine fish landings (tons) in 2007. 
fisheries dependent (e.g., from catch and landing reports) or fisheries independent (e.g., from scientific surveys). Rarely does a single fishery have data on the fish, fishers, and the environment, and an understanding of their interactions, sufficient for decision making by management.

The objectives of fishery management vary worldwide but are generally consistent with those in the United States. These are stated in the Magnuson-Stevens Fishery Conservation and Management Reauthorization Act of 2006 [8]. A fishery is (1) to provide the greatest overall benefit, including ecosystem services; (2) to provide the maximum sustainable yield, reduced for other factors (e.g., ecosystem function, bycatch); and (3) be rebuilt if overfished.

Fisheries management includes the sequence of observations, status indicators, informing management, and governance (Fig. 2). These steps are often repeated annually, though governance decisions may occur more frequently. Canonical management included observations consisting largely of fishery data (e.g., fish size, age, and abundance, from landings and surveys). These data are used in density dependent models of fish populations, i.e., models that depend only on the fish and include population size, spawning, growth, and natural and fishing mortality. Ideal management would also include ocean observations. While such observations are not yet commonly used in management, there is a growing understanding of the role of climate affecting fish productivity [9] and marine ecosystems [10].

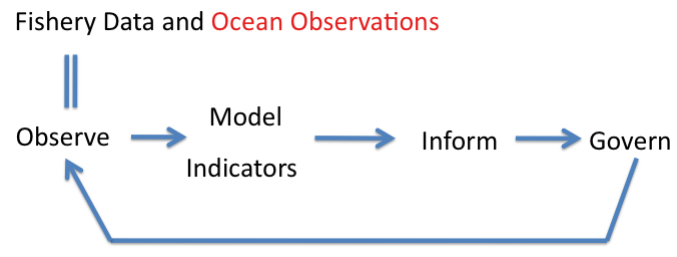

Figure 2. Canonical fisheries management (black). Ideal fisheries management (black with red).

\section{CASE STUDIES}

The US fishery for Pacific sardine (Sardinops sagax) is one of the few, and perhaps the only, marine fishery that uses environmental data directly in its management [11]. Per capital production of the Pacific sardine is greatest in warm ocean conditions [12] and high oceanic upwelling forced by the curl of the wind stress [13] (Fig. 3). The fraction of annual sardine production available to the fishery is determined by the water temperature at the end of the pier of the Scripps Institution of Oceanography (SIO) (warm, 15\%; cold, $5 \%$ ). This management strategy minimizes, and ultimately eliminates, fishing mortality of Pacific sardine under adverse environmental conditions and low population size.
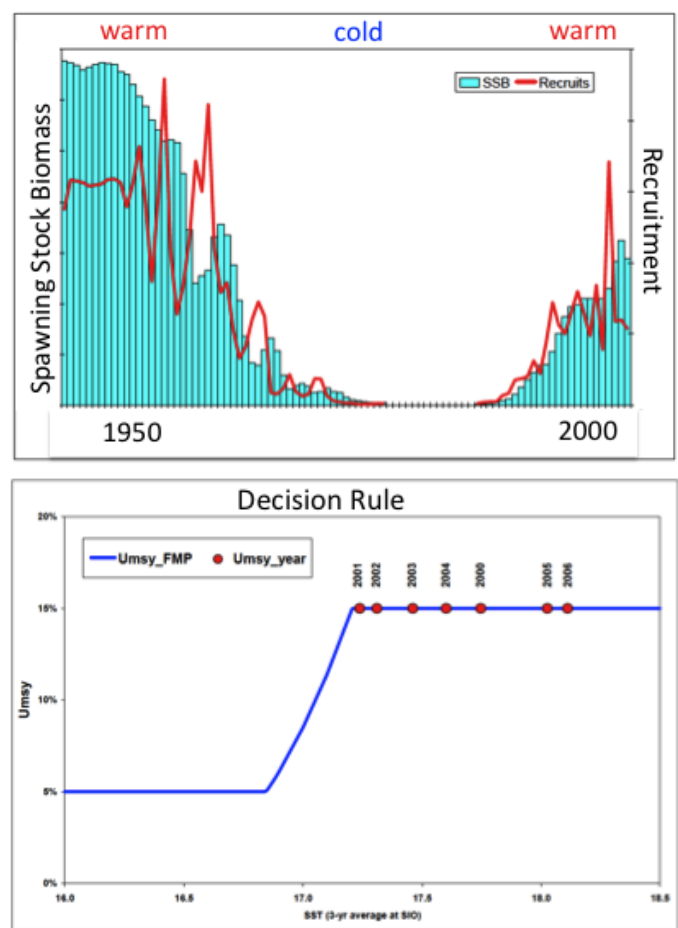

Figure 3. Pacific sardine spawning stock biomass and recruitment (upper) and management decision rule (lower). Sardine abundant during warm ocean periods. When SIO Pier Temperature falls below $17.2^{\circ} \mathrm{C}$, fraction of sardine biomass available for harvest decreases. [11]

The loggerhead sea turtle (Caretta caretta) is a protected species in the US and elsewhere and is a bycatch of the longline fishery for the North Pacific swordfish (Xiphias gladius). The habitat of the loggerhead turtles is known from the use of electronic tags, i.e., devices attached to the turtle that record data on date, time, location, and temperature. Remote observations of ocean temperature from satellites are

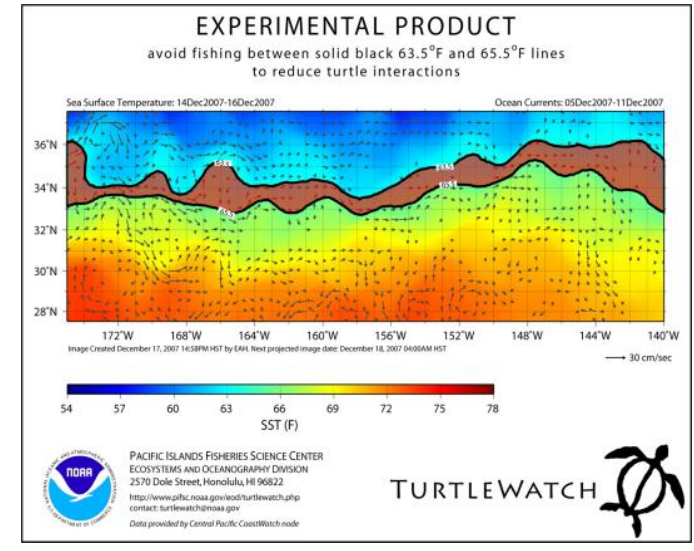

Figure 4. Loggerhead turtle habitat prediction, used to avoid bycatch in Pacific swordfish long-line fishery. [14]. 
then used with the habitat description to advise longline fishers where not to fish in order to minimize bycatch of loggerhead turtles (Fig. 4) [14].

Bluefin tuna (Thunnus maccoyii) is bycatch of the long-line fishery for tropical tuna off SE Australia. Electronic tags have been used with bluefin tuna to assess its habitat preferences. A numerical model (BLUElink (Ocean forecasting Australia), forced with satellite observations of ocean temperature and seasurface height, is used to create biweekly maps of bluefin tuna habitat. These, in turn, are used to advise long-line fishers where to avoid fishing to minimize bycatch of bluefin tuna off Australia (Fig. 5) [15].

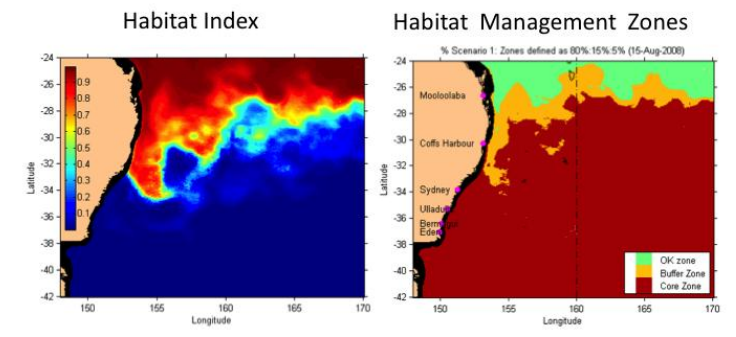

Figure 5. Southern bluefin tuna bycatch reduction. Maps of southern bluefin tuna habitat index (left) and avoidance zone for tropical tuna long-line fishery (right). [15]

\section{FUTURE NEEDS}

The needs of management are briefly presented below, working backward from governance, to informing decision makers, to models and indicators, and, finally, to observations. Relevance of observing is cited at each step.

\subsection{Governance}

Two main means of governing a fishery are catch and effort control. Catch control includes setting the total catch and, alone, often results in a 'race to fish' [16]. An alternative method is 'rights-based fishing', whereby catch shares are allocated to individual fishers who, as a result, assume responsibility for their share of the resource [17 and 18]. Catch shares as a management tool is increasing in use. Effort control includes restrictions on the time, area, and/or means (e.g., vessel size, mesh size, or number of hooks). Marine spatial planning, which includes area restrictions for fishing (e.g., marine protected areas), is also increasingly used.

Ultimately, governance is often affected not only by management recommendations based on natural science but also social science, including economics and politics. Thus, recommendations based on the best available natural science, including ocean observations, are often but one element considered in governance decisions.

\subsection{Models}

The science basis for management often requires models. There is a large range of model types. One dichotomy is between statistical and deterministic models. Both may rely on ocean observations. Statistical models characterize the past behavior of a population or system. They may be linear or nonlinear and often derive from analysis of time series of data. Such models are particularly valuable for short-term (e.g., months) forecasts [19]. Deterministic models are based on an understanding of interactions between variables, often atmosphere and ocean physics to chemistry to lower-trophic level biology and ecology. A general limitation of such models is our ability to predict the behavior of higher trophic level organisms, including fish and humans. In this regard, skill of prediction in both fisheries and economics share the common limitation in our understanding of behavior. Deterministic models of systems from physics to fish include NEMURO (North Pacific Ecosystem Model for Understanding Regional Oceanography) [20] and SEAPODYM (Spatial ecosystem and Population dynamics model) [21].

Models also vary in extent and complexity [22]. Single-species population models (e.g., stockrecruitment and age-structured models) form the basis of canonical fisheries management [23]. Density dependence is assumed. Ecosystem models range from box models [24] to individual-based models [25, 26 and 27] to models with physiology and behavior [20]. End-to-end models, such as Atlantis [28], simulate an entire system, including physical forcing, target species assessment and dynamics, and governance. Each type of model has different observation requirements.

\subsection{Indexes}

Fish stocks and ecosystems, like economies, are complex and require many variables for their full characterization, if feasible at all. Indexes are increasingly used to characterize the state of these phenomena. Climate indexes are used to characterize El Niño Southern Oscillation, ENSO (Southern Oscillation Index) [29], the North Atlantic Oscillation (NAO) [30], and the Pacific Decadal Oscillation (PDO) [31] . Biological indexes include mean trophic level [32], the Ocean Production Index [33], sentinel species abundance [34 and 35], and fish metrics (e.g., maximum species yield, food web-based yield, and species-diversity based yield [36 and 37]). In each case, the index is an abstraction of a salient aspect of the phenomenon. As for indexes used in economics 
(e.g., Dow Jones Industrial Average, Nikkei 225, and FTSE 100), indexes are increasingly used to assess the state and forecast the future of fish stocks and ecosystems [38].

\subsection{Observations}

Ocean observations needed for fisheries management are diverse and, because few are used now, it is not well known which are likely will be used most in the future. Likely physical variables include standard meteorological measurements (e.g., air temperature, barometric pressure, wind, and humidity); water column pressure, temperature, salinity, density, irradiance; stratification and mixing; currents $(u, v, w$ components of velocity); turbulence $(\varepsilon)$; and sea level height. Chemical variables include dissolved oxygen and carbon dioxide, $\mathrm{pH}$, nutrients, and photosynthetic pigments (e.g., chlorophyll $a$ ). Each of these can be measured directly (in situ) and some from space (e.g., surface water temperature, near-surface chl $a$, winds, sea-surface height, and, soon, salinity [39]).

Biological data include the distribution, abundance, and movement (e.g., migration) of phytoplankton, zooplankton, fish, birds, reptiles, and mammals. For many, it is useful to resolve age, size, and/or developmental stage (e.g., egg, larva, juvenile, and adult). Interactions, especially predator-prey, often from gut contents, must be known to understand dynamics. Direct observation and/or collection are necessary for many of these variables. Recent developments in observing using acoustics, optics, and molecular technologies show promise.

Finally, socioeconomic data are of increasing importance. These include information (e.g., values and costs) of commodities, human services, markets, trading, employment, and ecosystem services [40]. Governance decisions are not based on natural science alone but, also, 'human dimensions'. Such information is useful for 'end-to-end' models [28] as well as independently [41]. Within the natural sciences, it is usually apparent what choices exist for a common currency (e.g., dry mass, C, N, or energy). This is less clear when considering both natural and social sciences [42].

\section{CURRENT TOPICS}

\subsection{Integrated Ecosystem Assessments}

Ecosystem-based management (EBM) and, thus, the use of ocean observations in fisheries management are in their infancy. One strategy proposed for EBM is the Integrated Ecosystem Assessment (IEA) [43]. This procedure consists of first identifying the goals of
EBM and threats to achieving these and developing ecosystem indicators and targets, followed, iteratively, by risk analysis, assessment of ecosystem status relative to EBM goals, management strategy evaluation, and monitoring of ecosystem indicators and management effectiveness. Regardless of the exact methods used in EBM, observations of the ecosystem and the fished stocks will be necessary.

\subsection{Sensors and platforms}

New technologies will enable observations needed for future management. Ecosystem research needs rapid, accurate, and automated identification and assessment of individuals and groups. Such observations are needed, in part, for comparison with physical, chemical, and some biological data assessed remotely, routinely, and at high frequency.

Sensors include acoustic, optical, and molecular technologies. Ship-mounted sensors using active acoustics now enable 3D acoustic imaging of aggregations of fish and large zooplankton [44]. A range of optical imaging sensors, combined with computer-based image analysis, exist and continue to be developed [45]. Molecular sensors are being developed for genomics (species) and proteomics (proteins) [46]. In general, these technologies vary from far-field and low specificity (acoustics) to nearfield and high specificity (genomics, proteomics). Their combined and complementary use may be optimal. A common characteristic of these sensors is high bandwidth, i.e., large amounts of data, with attendant needs for data storage and processing.

Platforms on which sensors are deployed are varied and increasing in capability. Satellites provide nearregular and synoptic view of sea surface temperature and height, winds, and ocean color ( phytoplankton concentration); salinity is forthcoming [47]. Ships enable observations on grids of stations (e.g., CalCOFI (California Cooperative Oceanic Fisheries Investigations)) [48] and underway (e.g., Continuous Plankton Recorder [49], Continuous Underway Fish Egg Sampler [50], Moving Vessel Profiler [51], and towed undulating vehicles [52]). Vessel monitoring systems (VMS [53 and 54]), most notably on fishing vessels, provide information on fleet activities and, potentially, the environment. Autonomous, semiLagrangian platforms include floats, gliders, and AUVs [55]. Eulerian platforms include shore stations (e.g., for sea level) and moorings with both surface and subsurface buoys; autonomous profiling capabilities exist and continue to be developed [56, 57 and 58]. Finally, animals are increasingly used as platforms for sensors by use of tags (archival and pop-up satellite), biologging (e.g., instruments attached temporarily to 
marine mammals) [59], and acoustic listening networks, in which animals with implanted sensors are detected at listening nodes [60].

\section{CHAllengeS}

The use of ocean observations in fisheries management presents challenges. Some are listed below.

No silver bullet - Beth Fulton [61] noted that fish stocks vary in their management needs, including observations. Thus, unlike some large observing programs, such as Argo (Array for Real-time Geostrophic Oceanography) [62], with highly standardized protocols, individual fisheries will require adaptive management and observing.

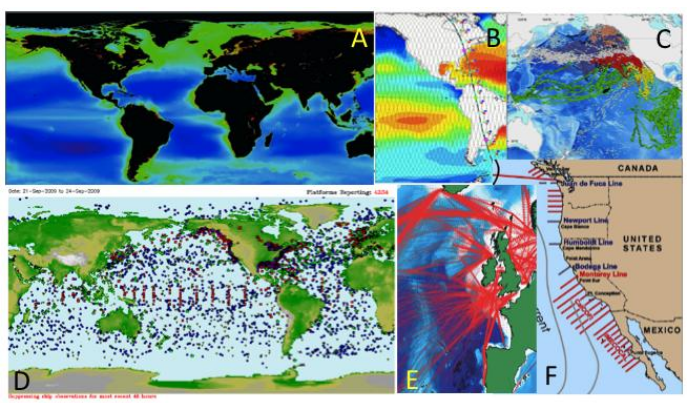

Figure 6. Montage of observation types illustrating their diversity and hence the challenge of using all for the common goal of fisheries management. A. SeaWiFS chl a. B. Sea surface salinity. C. Tracks of tagged animals. D. JCOMM hydrographic observations (21-24 September 2009). E. Continuous Plankton Recorder (CPR) tracks. F. US West Coast hydrography and plankton sampling lines.

Time-space variation - Biological and ecosystem distributions and processes are not uniform in time and space but, rather, are often aggregated and episodic. Examples include plankton patches and blooms and fish schools and spawning. Observing such variable distributions and processes requires special strategies, e.g., continuous sampling and rapid sample and data processing.

Species interactions - Knowledge of trophic interactions is essential to understand, hence predict, ecosystem dynamics. Analysis of the contents of guts of consumers remains the basic method. However, novel methods involving genomics, proteomics, and optical imaging may be used to analyze gut contents. The nutritional value (e.g., energy content [63]) of food and the rate of feeding are also needed.

Scale and type of observations - Ocean observations for fisheries management vary widely in their temporal and spatial scales, and in other characteristics (Fig. 6). Thus, data on physics, chemistry, and biology often have scale and other mismatches. Effort is needed to enable the use of these disparate types of data for management. Indexes may be useful.

Human dimensions - Governance, hence management, ultimately involves the human dimension. Social science observations will be increasingly necessary for management and governance decisions. Using observations in the natural and social sciences for the common purposes of fisheries management will require novel methods.

Risk and uncertainty - Assessment and prediction of populations and ecosystems must include risk and uncertainty. Sources of variability include weather and climate and the behavior of both fish and humans. Future scenarios with associated probabilities may be useful to predict.

Data access - Access to data should be as rapid and open as reasonable. This is the case now for many types of data (e.g., CalCOFI [47], CPR (Continuous Plankton Recorder) [48], and Argo data [62]) but not others (e.g., some fisheries data are proprietary). Free and open access to data facilitates its use in a timely manner by scientists and decision makers.

Participation - Management decisions affect the fished stock, the ecosystem of which it is a part, and the fishers and their communities. The success of governance depends on recommendations based on both the natural and social sciences and the respect and trust of fishers and other stakeholders. Thus, participation by stakeholders, scientists, and managers is essential.

Coastal observing and capacity building - Many fisheries, from large-scale, production (e.g., Peruvian anchoveta, Baltic cod) to small-scale, artisanal (e.g., SE Asia), occur in coastal waters. Observing, modeling, and understanding are often more limited in these areas than in oceanic regions. Greater emphasis on observing in coastal waters is needed. Similarly, capacity building for ocean observing, particularly in coastal regions, is needed. [56 and 58]

\section{OCEANOBS'19 PREDICTIONS}

Ocean observations will be critical to fisheries management by OceanObs'19. This is based on acknowledgement of both the increasing demand to manage fisheries in the context of the ecosystem and the increased capabilities of observing. It will be facilitated by an increased understanding of the relation of fisheries to the environment. The increased use of ocean observations for fisheries management will be 
shared by developing and developed countries alike, due to both need and capacity building.

Climate change effects on fisheries will be apparent due, in part, to enhanced ocean observing. The main effects will be due to rising sea level, warming, deoxygenation, and acidification [64]. Many of these effects will be most acute in coastal regions.

\section{ACKNOWLEDGEMENTS}

I am grateful to the following individuals who provided input on this topic prior to my presentation at OceanObs'09 in Venice, Italy, in September 2009: Steven Bograd, Keith Brander, Nick Caputi, Dave Demaster, Beth Fulton, Pierre Fréon, Renato Guevara, Alastair Hobday, Anne Hollowed, Brian MacKenzie, Lorenzo Motos, Francisco Neira, Yoshioka Oozeki, Ian Perry, Bill Peterson, Benjamin Planque, Jeff Polovina, Ryan Rykaczewski, Svein Sundby, Carl van der Lingen, Yoshiro Watanabe, and George Watters. I also thank the OceanObs'09 Organizing Committee for inviting me to present this work.

\section{REFERENCES}

1. Jennings, S., Kaiser, M.J., \& Reynolds, J.D. (2001). Marine Fisheries Ecology, Blackwell, Oxford, UK.

2. Hilborn, R. (2007). Managing fisheries is managing people: what has been learned? Fish Fisheries 8(4): 285-296.

3. Cushing, D.H. (1982). Climate and Fisheries. Academic Press, New York, USA.

4. Lehodey, P., Alheit, J., Barange, M. \& 10 co-authors (2006). Climate variability, fish, and fisheries. J. Climate 19: 509-530.

5. Brander, K.M. (2007). Global fish production and climate change. Proc. Nat. Acad. Sci. 104(50): 19709-19714.

6. FAO Fisheries Statistics, accessed 2 February 2010 at http://www.fao.org/fishery/statistics/en

7. Stobutzki, I. C., Silvestre, G.T. \& Garces, L.R. (2006). Key issues in coastal fisheries in South and Southeast Asia, outcomes of a regional initiative. Fish. Res. 78: 109-118.

8. Magnuson-Stevens Fishery Conservation and Management Reauthorization Act of 2006, accessed on 2 February 2010 http://www.nmfs.noaa.gov/msa2007/index.html

9. Lindegren, M., Möllmann, C., Nielsen, A., and Stenseth, N.C. (2009). Preventing the collapse of the Baltic cod stock through an ecosystem-based management approach. Proc. Nat. Acad. Sci. 106(34): 14722-14727.
10. Stenseth, N.C., Ottersen, G., Hurrell, J.W., and Belgrano, A. (2004). Marine Ecosystems and Climate Variation. Oxford U. Press, Oxford, UK.

11. Hill, K.T., Lo, N.C.H., Macewicz, B.J., \& Felix-Uraga, R. (2006) Assessment of the Pacific sardine (Sardinops sagax caerulea) population for U.S. management in 2007. U.S. Dept. Commerce NOAA-TM-NMFSSWFSC-396. $102 \mathrm{pp}$.

12. Jacobson, L.D. \& MacCall, A.D. (1995). Stockrecruitment models for Pacific sardine (Sardinops sagax). Can. J. Fish. Aq. Sci. 52(3): 566-577.

13. Rykaczewski, R.R. \& Checkley, D.M., Jr. (2008). Influence of ocean winds on the pelagic ecosystem in, upwelling regions. Proc. Nat. Acad. Sci. 105: 19651970.

14. Howell, E.A., Kobayashi, D.R., Parker, D.M., \& Polovina, J.J. (2008). TurtleWatch: a tool to aid in the bycatch reduction of loggerhead turtles Caretta caretta in the Hawaii-based pelagic longline fishery. Endang. Sp. Res. 5: 267-278.

15. Hobday, A.J. \& Hartmann, K. (2006). Near real-time spatial management based on habitat predictions for a longline bycatch species. Fish. Man. Ecol. 13(6): 365380 .

16. Hilborn, R. (2007). Managing fisheries is managing people: what has been learned? Fish Fisher. 8(4): 285 296.

17. Costello, C., Gaines, S.D., \& Lynham, J. (2008). Can catch shares prevent fisheries collapse? Science 321(5896): 1678-1681.

18. Essington, T.E. 2010 Ecological indicators display reduced variation in North American catch share fisheries. Proc. Nat. Acad. Sci. 107(2): 754-759.

19. Hanson, P.J., Vaughan, D.S., \& Narayan, S. (2006). Forecasting annual harvests of Atlantic and Gulf Menhaden. N. Am. J. Fisher. Man. 26(3): 753-764.

20. Kishi, M. J., Kashiwai, M. \& 27 co-authors. (2007). NEMURO - a lower trophic level model for the North Pacific marine ecosystem. Ecol. Mod. 202(1-2): 12-25.

21. Lehodey, P., Senina, I., Sibert, J., \& 4 co-authors. (2010). Preliminary forecasts of Pacific bigeye tuna population trends under the A2 IPCC scenario. Prog. Oceanogr. 86(1-2): 302-315.

22. Lett, C., Rose, K.A., \& Megrey, B.A. (2009). Chapter 6. Biophysical models. In Checkley, D.M., Jr., Alheit, J., Oozeki, Y., and Roy, C. Climate Change and Small Pelagic Fish, Cambridge University Press, Cambridge, UK. 
23. Quinn, T.J. \& Deriso, R.B. (1999). Quantitative Fish Dynamics. Oxford, New York, USA.

24. Franks, P.J.S. (2002). NPZ models of plankton dynamics: Their construction, coupling to physics, and application. J. Oceanogr. 58(2): 379-387.

25. Gallego, A., North, E.W. \& Petitgas, P. (2007). Introduction: status and future of modelling physicalbiological interactions during the early life of fishes. Mar. Ecol. Prog. Ser. 347: 122-126.

26. Grimm, V., U. Berger, \& 26 co-authors (2006). A standard protocol for describing individual-based and agent-based models. Ecol. Mod. 198(1-2): 115-126.

27. Hinckley, S., Hermann, A.J., \& Megrey, B.A. (1996). Development of a spatially explicit, individual-based model of marine fish early life history. Mar. Ecol. Prog. Ser. 139(1-3): 47-68.

28. Fulton, E. A., Smith, A.D.M. \& Smith, D.C. (2007). Alternative Management Strategies for Southeast Australian Commonwealth Fisheries: Stage 2: Quantitative Management Strategy Evaluation, CSIRO: 408pp.

29. Rasmusson, E.M. \& Carpenter, T.H. (1982). Variations in tropical sea surface temperature and surface wind fields associated with the Southern Oscillation/El Niño. Mon. Weather Rev. 110: 354-384.

30. Hurrell, J.W. \& Van Loon, H. (1997). Decadal variations in climate associated with the North Atlantic Oscillation. Climatic Change 36(3-4): 301-326.

31. Mantua, N.J., Hare, S.R., Zhang, Y., Wallace, J.M., \& Francis, R.C. (1997). A Pacific interdecadal climate oscillation with impacts on salmon production. Bull. Am. Met. Soc. 78(6): 1069-1079.

32. Pauly, D., Christensen, V., Dalsgaard, J., Froese, R., \& Torres, F. (1998). Fishing down marine food webs. Science 279(5352): 860-863.

33. Peterson, W.T., \& Schwing, F.B. (2003). A new climate regime in northeast pacific ecosystems. Geophys. Res. Let. 30(17).

34. Gremillet, D., Lewis, S., Drapeau, L., \& 7 co-authors (2008). Spatial match-mismatch in the Benguela upwelling zone: should we expect chlorophyll and seasurface temperature to predict marine predator distributions? J. App. Ecol. 45(2): 610-621.

35. Pichegru, L., Ryan, P.G., van der Lingen, C.D., \& 3 coauthors (2007). Foraging behaviour and energetics of Cape gannets Morus capensis feeding on live prey and fishery discards in the Benguela upwelling system. Mar. Ecol. Prog. Ser. 350: 127-136.
36. Collie, J.S., Gifford, D.J., \& J.H. Steele et al. (2009). End-to-end foodweb control of fish production on Georges Bank. ICES J. Mar. Sci. 66(10): 2223-2232.

37. Gifford, D.J., J.H. Steele, \& Collie, J.S. (2009)

Combining constraints from predation and competition to determine expected fishery yields on Georges Bank. Unpublished talk S6-05, GLOBEC Open Science Meeting, Victoria, Canada.

38. Jennings, S. (2005). Indicators to support an ecosystem approach to fisheries. Fish Fisheries 6(3): 212-232.

39. Font, J., Lagerloef, G.S.E., Le Vine, D.M., \& 2 coauthors (2004). The determination of surface salinity with the European SMOS space mission. IEEE Trans. Geosci. Rem. Sens. 42(10): 2196-2205.

40. Herrick, Jr., S.F., Norton, J.G., Hannesson, R. \& 3 coauthors. Chapter 10. Global production and economics. In Checkley, D.M., Jr., Alheit, J., Oozeki, Y., and Roy, C. Climate Change and Small Pelagic Fish, Cambridge University Press, Cambridge, UK.

41. Rosemary E. Ommer, R.E., Jarre, A.C., Perry, R.I. \& 3 co-authors Chapter 11. Human dimensions of the fisheries under global change. In Checkley, D.M., Jr., Alheit, J., Oozeki, Y., and Roy, C. Climate Change and Small Pelagic Fish, Cambridge University Press, Cambridge, UK.

42. Sumaila, U.R. (2005). Differences in economic perspectives and implementation of ecosystem-based management of marine resources. Mar. Ecol. Prog. Ser. 300: $279-282$.

43. Levin, P.S., Fogarty, M.J., Murawski, S.A., Fluharty, D. (2009). Integrated Ecosystem Assessments: Developing the scientific basis for ecosystem-based management of the ocean. PLoS Biol. 7(1): 23-28.

44. Korneliussen, R. J., Y. Heggelund, Eliassen, I.K. \& 3 coauthors (2009). Combining multibeam-sonar and multifrequency-echosounder data: examples of the analysis and imaging of large euphausiid schools. ICES J. Mar. Sci. 66(6): 991-997.

45. Sieracki, M. \& Co-Authors (2010). "Optical Plankton Imaging and Analysis Systems for Ocean Observation" in these proceedings (Vol. 2), doi:10.5270/OceanObs09.cwp.81.

46. Goodwin, K.D. \& Litaker, R.W. (2008). Emerging technologies for monitoring recreational waters for bacteria and viruses. In Walsh, P.J., Smith, S.L., Fleming, L.E., Solo-Gabriele, H., \& Gerwick, W.H. eds. Oceans and Human Health: Risk and Remedies from the Seas. Elsevier, New York.

47. Font, J., Lagerloef, G.S.E., Le Vine, D.M., Camps, A., Zanife, O.Z. (2004). The determination of surface 
salinity with the European SMOS space mission. IEEE Trans. Geosci. Rem. Sens. 42(10): 2196-2205.

48. Koslow, J., Goericke, R., McClatchie, S., Vetter, R. and Rogers-Bennett, L., (2010). "The California Cooperative Oceanic Fisheries Investigations (CalCOFI): The Continuing Evolution and Contributions of a 60-Year Ocean Observation Program" in these proceedings (Vol. 2), doi:10.5270/OceanObs09.cwp.49.

49. Reid, P. \& Co-Authors (2010). "A Global Continuous Plankton Recorder Programme" in these proceedings (Vol. 2), doi:10.5270/OceanObs09.cwp.73.

50. Checkley, D. M., Jr., P. B. Ortner, Settle, L.R., Cummings, S.R. (1997). A continuous, underway fish egg sampler. Fish. Oceanogr. 6: 58-73.

51. Moving Vessel Profiler, ODIM Brooke Ocean, accessed on 3 February 2010 at http://www.brookeocean.com/mvp_main.html

52. Strass, V.H. (1992). Chlorophyll patchiness caused by mesoscale upwelling at fronts. Deep-Sea Res. Part A 39(1A): 75-96.

53. Witt, M.J. \& Godley, B.J. (2007). A step towards seascape scale conservation: using vessel monitoring systems (VMS) to map fishing activity. PLoS One 2(10): $5 \mathrm{p}$

54. Bertrand, S., Dewitte, B., Tam, J., \& 2 co-authors (2008). Impacts of Kelvin wave forcing in the Peru Humboldt Current system: Scenarios of spatial reorganizations from physics to fishers. Prog. Oceanogr. 79(2-4): 278289.

55. Dickey, T.D., Itsweire, E.C., Moline, M.A., and Perry, M.J. (2008). Introduction to the Limnology and Oceanography Special Issue on Autonomous and Lagrangian Platforms and Sensors (ALPS). Limnol. Oceanogr. 53(5): 2057-2061.

56. Malone, T. \& Co-Authors (2010). "Building a Global System of Systems for the Coastal Ocean" in these proceedings (Vol. 2), doi:10.5270/OceanObs09.cwp.59.

57. Send, U. \& Co-Authors (2010). "OceanSITES" in these proceedings (Vol. 2), doi:10.5270/OceanObs09.cwp.79.

58. Send, U. \& Co-Authors (2010). "A Global Boundary Current Circulation Observing Network" in these proceedings (Vol. 2), doi:10.5270/OceanObs09.cwp.78.

59. Boehme, L. \& Co-Authors (2010). "Biologging in the Global Ocean Observing System" in these proceedings (Vol. 2), doi:10.5270/OceanObs09.cwp.06.
60. O'Dor, R. \& Co-Authors (2010). "The Ocean Tracking Network" in these proceedings (Vol. 2), doi:10.5270/OceanObs09.cwp.66.

61. Fulton, E., Smith, A.D.M., \& Smith, D. No silver bullets. . Unpublished talk S6-08, GLOBEC Open Science Meeting, Victoria, Canada

62. Freeland, H. \& Co-Authors (2010). "Argo - A Decade of Progress" in these proceedings (Vol. 2), doi:10.5270/OceanObs09.cwp.32.

63. Hartman, K.J. \& Brandt, S.B. (1995). Estimating energy density of fish. Trans. Amer. Fish. Soc. 124(3): 347355.

64. Intergovernmental Panel on Climate Change (IPCC) (2007). Climate Change 2007: Synthesis Report. IPCC, Geneva, Switzerland. 